Revue d'études américaines. American Studies Journal

$2 \mid 2017$

(Hi)stories of American Women: Writings and Rewritings / Call and Answer: Dialoguing the American West in France

\title{
Memories of Slavery and Colonization: Historiography, Arts, Museums
}

Le Mans Université, November 9-10, 2017

Ana-Catharina Santos-Silva

\section{(2) OpenEdition}

Electronic version

URL: https://journals.openedition.org/transatlantica/10312

DOI: 10.4000/transatlantica.10312

ISSN: 1765-2766

Publisher

Association française d'Etudes Américaines (AFEA)

Electronic reference

Ana-Catharina Santos-Silva, "Memories of Slavery and Colonization: Historiography, Arts, Museums", Transatlantica [Online], 2 | 2017, Online since 22 May 2019, connection on 02 February 2023. URL: http://journals.openedition.org/transatlantica/10312 ; DOI: https://doi.org/10.4000/transatlantica. 10312

This text was automatically generated on 2 February 2023.

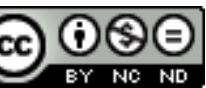

Creative Commons - Attribution-NonCommercial-NoDerivatives 4.0 International - CC BY-NC-ND 4.0 https://creativecommons.org/licenses/by-nc-nd/4.0/ 


\title{
Memories of Slavery and Colonization: Historiography, Arts, Museums
}

Le Mans Université, November 9-10, 2017

\author{
Ana-Catharina Santos-Silva
}

1 The conference Memories of Slavery and Colonization: Historiography, Arts, Museums, held at Le Mans University under the supervision of Delphine Letort, Eliane Elmaleh, Benaouda Lebdai (3L.AM, Le Mans Université), and Claudine Raynaud (Emma, Université Paul Valéry Montpellier 3) featured a very noticeably international selection of speakers. Researchers from France, Mali, Benin, Turkey, the United States, Cameroon, and Senegal took part in four different workshops on different themes: Museums and Monuments, Slavery in Literature, Visual Representations of Slavery, and Historiography.

2 The first day of conference started with Workshop 1, where presentations revolved around the role of Museums and Monuments in the memory(ies) of slavery. Renée Gosson was the first to speak: the researcher spoke about staging strategies in museums when depicting the slave experience. She mentioned, among others, the Musée d'Histoire de Nantes - a museum on Nantes's history from the Middle Ages to nowadays, whose museography, she argued, does not assign enough space to the human and sentimental experience of slavery. She also showed how the museum fails to connect slavery with its broad social consequences, such as contemporary racism. She cited Françoise Vergès to support her point: "Slaves enter the economy as labor, but also as human beings with blood, dreams, despair, and languages." The museum "must maroon," in reference to the maroon slaves who managed to escape and build their own narratives of resistance. She also spoke about the museography of MACT (Guadeloupe's Memorial ACTe), which she does not view as a museum per se, but more as a space for other cultural events. She criticized it for rushing to the reconciliation of memories. One of the most important questions she raised dealt with the nature of museums: is it even possible to provide a balance between emotional representations of 
the slave experience and the objective realities of slavery without ever falling into theme park-like representations? Gosson also discussed how museums represent typically western points of view, opening up for debate an essential memory-related issue on the conference's first day.

3 Afterwards, Anne-Claire Faucquez presented the case of the New York Burial Ground National Monument. Damaging excavations on this archeological site prompted the Federal Government to declare it a national monument. Faucquez analyzed a series of art pieces commemorating the sacred site and used them to illustrate the meanings of commemorative art. One of the points she discussed is the political assertion behind commemorative art - one of comfort and psychological healing - as well as the homogenizing tendency in the perpetuation of an African memory.

4 Inge Zwart's then showed how the Netherlands has, slowly but surely, begun to commemorate its colonial past as part of its national history. She explained how the concept of shared history has been used in museums in both the Netherlands and its former colonies, such as Curaçao and Suriname. By analyzing the museography of those museums, she spoke about issues regarding the concept of shared history and its misleading claims to "shared memories," since one has to consider whose voice is heard, and how. (See the Savonnet museum in Curaçao, which is located on the grounds of a former plantation: what is the meaning of a colonial museum inside a colonial house? What message is this setting supposed to convey?). She insisted on the importance of the memory left in the present, since it is that memory which conditions one's idea of history. Zwart's considerations on the importance of focusing on present memory and its underlying power dynamics echoed important points on memory, representation, and narrative raised earlier in the workshop.

5 Androula Michael's presentation allowed the discussion to shift to specific manifestations of post-colonial reaction in art. She used the performance of artist JeanFrançois Boclé as a starting point: an off-screen narrator reads a text, which the artist writes down on a blackboard. The dictation happens to be the Black Code - a 1685 set of rules created under Louis XIV and regulating the practice of slavery in the Empire. As a result of the board's limited space, the artist ends up writing over previous words and covering the entire board with white chalk. Using this performance, the researcher opened up her argument on memory and used the works of other artists - such as Barthélémy Toguo, Kader Attia and Jonathas de Andrade - to explain how each of them found different ways to respond to post-colonial memory. Androula Michael raised the difficulty of mourning imaginary bodies generation after generation, as well as the challenges behind long-lasting mourning. She closed her presentation by asserting the necessity of overcoming any colonialist conceptions that still underlie many of our representations.

6 Turning to music, Sally-Ann Schutz set out to explore regional Southern Colonialism. She scrutinized the practices of white music producers who collected and appropriated Black Folk music. "Each minute of black song picked by a white collector is a conversation between colonizer and colonized," Schutz asserted. The search for authenticity exoticized Black people, as shown by the example of John Lomax and the reproduction of a plantation-like musical atmosphere. The search for musical authenticity is also the search for an ill-defined "racial authenticity." The myth of the old South, with its uncles and mammies, built on this search for racial genuineness. In the process, blackness framed and enhanced whiteness. Even today, authenticity and 
primitiveness are still used as positive criteria to define good music, suggesting that the decolonization of music is still necessary, while reminding us that "music is a possession from a dispossessed past".

7 In the afternoon, Michael T. Martin's keynote started with cinematic memory as a conceptual apparatus (he explained how it can be periodically revised, in keeping with his concept of four classes of memory), and then talked about slavery as a critical, trans-historical category. He finally explained how museums can now do more than simply shelter documents and artefacts, but spark debates and deconstruct narratives of dominations. In his concluding remarks, Martin emphasized the necessity for museums to not only educate, but open up discussions on current topics which are rooted in the past and yet shape our future.

Workshop 2 approached slavery in literature, with presentations of Jacqueline Jondot, Katie Tidmarsh, Alfred Djossou, Ece Yassitepe Ayyildiz and Adiaba Vincent Kablan, while Workshop 3 focused on Visual Representations of Slavery. Delphine Letort opened the session with her presentation on slave rebellions on screen: through the example of the new version of Birth of a Nation (2016), she pointed out the film's change of focus from its original version: Nate Parker's movie foregrounds the protagonist's intelligence as well as maroons' aspirations to freedom and agency.

9 Still discussing film, Isabelle Le Corff analysed René Vaultier's politically committed cinema in Africa. She showed how low-budget militant movies (such as Algérie en Flammes) were instrumental in supporting anti-colonialist thought and bringing about different types of colonial memory.

Later on, still on the note of critical cinema, Josiane Ranguin analyzed how Melvin Van Peebles and Spike Lee have both exposed the foundations of racism, albeit through different strategies. The researcher showed how Van Peebles discusses how he was affected, at a young age, by construing Hollywood movies as moving evidence of trauma (Classified History X, 1997). Spike Lee's Bamboozled (2000) exposes how racism is still informed by persisting memories of slavery and colonialism, to the point that blackface can be resurrected and naturalized in a TV show. Bamboozled's final, voicedover sequence shows how, since antebellum times, racism has been deeply rooted in visual representations of African-Americans until present days. Due to this persistence, Ranguin classifies the footage as a moving "lieu de mémoire".

11 PhD student Christelle Gomis finished the afternoon with her presentation on how American narratives of slavery are often preferred over French ones, even among French audiences. She gave the example of the success of the American series Roots among Black French people. She also mentioned the 1998 march in Paris to commemorate slavery and asserted that such demonstrations are part of a process of strengthening people's awareness. Gomis contended that the presentation of Africa as homeland and the importance given by Roots to racist colonialism helped viewers connect and bond over feelings of injustice. The more important impact Roots had on French Black spectators, however - and on Black people living in former colonies - is also due to the fact that when French series such as Tropiques Amers portray chattel slavery, they usually emphasize the French Republic's "heroic" move toward abolitionism while downplaying slaves' role. Gomis concluded her paper by asserting the importance of using visual sources from different countries to de-historicize French chattel slavery. 
12 The second and last conference day started with Felwine Sarr's keynote on History, memory, and self-reinvention. The conditions for the regeneration and resilience of the African people(s) are at the center of Sarr's work. He also focused on what should be done with recent history as well as the right use of history and memory: a history that is researched, a Historia. He wants to name all that once was, all that once was abolished, and everything that matters - a science of trace, which he attributes to Marc Bloch. For Sarr, articulating memory and history is extremely important, since memory nourishes and completes history. However, he also insisted that one should consider the influence of power on this articulation, since each form of power rests on the construction of a narrative, and each narrative is an experience of reality. In Sarr's mind, a historian must take memory in consideration in their research, while remaining fully aware that the existence of memory does not prevent history from being questioned (i.e. Revisionism against the memory of the Shoah). The scholar pointed out that a lack of confidence and an inferiority complex (resulting from colonialism) in the African continent have tended to prevent the reconstruction of a historical past. Sarr asserted that history should be not so much a work of memory as a work on memory. He sees reality committees (which allow historical realities such as slavery to resurface) as means of making justice and opening a door towards the future. Sarr concluded his speech by saying that every tradition should be taken in consideration by keeping what is vital, fundamental, and fertile, while claiming its place in history.

In the afternoon, the workshops originally planned in different rooms were eventually held together. The session started with Professor Lebdai's presentation on the importance of visual geography to slavery. In the novels of Armah, oceans and rivers are extremely salient. Lebdai thus spoke about this close bond between slavery and the motif of water, evidencing its brutal connections with the memory of slavery as well as its dual aspect - at once the source of life and a tragic component of the slave trade. The immobility of the men and women held captive inside the ships mirrors that of the African continent during the slave trade era, with the smell of the sea a constant reminder of tragedy. Lebdai also pointed that Armah used water as an element permeating the sub-consciousness of characters (whose names humanize every experience in Armah's stories): the sea is seen as a giant cemetery in which dead bodies sink, forever forgotten. On the other hand, rivers are a source of life and happy memories. Lebdai characterized the sea and the river as metaphors for the aggressiveness of the white colonizer and the serenity and freshness of African men and women, respectively. Contrary to Western novels, where the sea is an open door to adventures and conquering power, Lebdai showed that, in Ghanaian novels, oceans are viewed from opposite perspectives. Ever in motion, Africans themselves are not stagnant but falling waters. Lebdai views these conflicting ideas on water as a metaphor of the post-colonial situation.

Moving onto the topic of museums, Hannelore Vandenbergen made a presentation on the contextualization of several objects of the Hutereau collection at the Royal Museum of Central Africa in Tervuren. This effort is especially challenging, owing to the conditions in which those objects were collected: Hutereau notably used porters to collect those objects by the Uélé and Faradje rivers. Vandenbergen looks for social relations among those objects, considering, of course, the racist and evolutionist context of Belgium at the time of their collection. For the researcher, the fate of porters 
is important, as their narratives are proof of the cruelty of colonialism and racism. In an inspiring and emotional presentation, she asserted that it is now time to name and remember those atrocities. Vandenbergen concluded her presentation by saying that issues of power remain a problem, and that mere awareness of slavery and its political consequences nowadays is not enough: reparations must be made.

Still on indigenous peoples and memory but this time in North America, Robert Atkinson recorded three narratives of native history in different Californian museums in summer 2017. In the state narrative, the hero is the Euro/American capitalist settler, whose story is linear; racism and assimilationism are the norms. By contrast, the church narrative favors a fantastical tale of peaceful, willful conversions. The third is a tribal narrative, which shows the hero as a tribe member and focuses on restoring the tribe's sovereignty in a non-linear, annual earth renewal process. More than presenting the different versions of history and their effects on different groups' memories, Atkinson emphasized that Native Americans, the group which has suffered the most since the construction of the state of California, do not so much commemorate tragedies as they emphasize aspects of their survival. Therefore, Atkinson showed that for those Native Americans the presentation of memory does not entail commemorating painful events with monuments explaining the social struggles the group has been through.

The afternoon - and final - session was opened by Clint Bruce, whose presentation revolved around the following question: can the Acadian community find a place in its history for the memory of slavery?

The scholar emphasized the importance of slavery and racial dynamics in Acadian identity: the Black population influenced White Acadians in the areas of music, food, and other cultural aspects. Bruce explained that for a very long time the word "Cajun" was derogatory and that the museal reconstitution of this identity has been meant to present the Cajuns differently and improve their image. To this end, bringing up the memory of slavery is important to help today's Acadians reconsider their own memory - there is often astonishment when some find out that people they once saw as heroes in their own communities took part in the slave trade.

Later on, Abboubacar talked about how Russians came in contact with the African continent. Using narratives of Egypt-based Russian merchants and pilgrims, the researcher explained how the latter helped shape relations between European and African worshippers in Jerusalem. Maiga concluded by underlining the importance of those narratives for the contemporary era: by the time the first African students arrived in the Soviet Union in the fifties, some Soviet citizens already based their representation of the African continent on those pilgrims' and travelers' writings.

Andrew Houck presented an analysis on a very topical subject: the symbols commemorating the Confederate States and the Civil War. Houck explained the complex context of Southern History, and later provided a brief topography of historical memory's cohabitation with the memory of the Lost Cause. Rather than draw conclusions, Houck questioned whether those two memories can coexist, since the Lost Cause continues to dominate much of the physical and imaginary aspects of Southern memory.

20 The conference was notably successful for its intersectional dialogues and the wide plurality of opinions expressed, all of which still addressed the theme of slavery's memories. The different approaches - literary, museographical, historical, and visual - 
helped evidence the complexity and many voices behind the theme. Since the Middle Passage has had a significant impact not only in the African Continent but in all the other countries connected to the trade, such a broad perspective was more than called for. Therefore we can conclude from the conference that while memories might start individually, they are nurtured and interpreted collectively and influenced by the specific contexts where they are perpetuated.

INDEX

Subjects: Actualité de la recherche

\section{AUTHOR}

ANA-CATHARINA SANTOS-SILVA

Le Mans Université 